\title{
Optimisation of fermentation conditions for bioethanol production from oil palm trunk sap by Saccharomyces cerevisiae
}

\author{
Bukhari Nurul Adela* and Soh Kheang Loh \\ Energy and Environment Unit, Engineering and Processing Division, Malaysian Palm Oil Board (MPOB), 6, Persiaran \\ Institusi, Bandar Baru Bangi, 43000 Kajang, Selangor. \\ Email: adela@mpob.gov.my
}

\begin{abstract}
Aims: Oil palm trunk (OPT) can be a potential biomass from replanting activities for biomass-to-liquid (BTL) particularly in bioethanol production. The OPT contains higher carbohydrates compared to other oil palm biomass, thus has better advantages as feedstock for biofuel. To realise this, the feasibility of using oil palm trunk (OPT) sap as a substrate for bioethanol fermentation was explored via optimising the various culture conditions $(\mathrm{pH}$, temperature, inoculum size, nitrogen source, dilution effect and growth medium) using Saccharomyces cerevisiae.

Methodology and results: A total of six parameters were tested for optimising bioethanol production i.e. $\mathrm{pH}$, temperature, inoculum size, nitrogen source, dilution effect and types of medium. Results showed that the optimum conditions for OPT sap in bioethanol production were at $\mathrm{pH} 4.0$, temperature of $30{ }^{\circ} \mathrm{C}$, inoculum size of $10 \%(\mathrm{v} / \mathrm{v})$, without requirement of nitrogen supplementation and substrate dilution. A fermentation period of $24 \mathrm{~h}$ was best for bioethanol production and resulted in bioethanol production, formation rate and yield of $47.5 \mathrm{~g} / \mathrm{L}, 1.98 \mathrm{~g} / \mathrm{h}$ and $0.50 \mathrm{~g} / \mathrm{g}$, respectively.

Conclusion, significance and impact study: The study has clearly demonstrated that high efficient bioethanol production from OPT sap is possible but it is susceptible to various fermentation influencing parameters. This study could establish an effective and sustainable utilisation of waste OPT especially its sap as a lignocellulosic biomass supplement from the oil palm industry for second generation biofuel production.
\end{abstract}

Keywords: Oil palm trunk sap, fermentation, Saccharomyces cerevisiae, bioethanol

\section{INTRODUCTION}

Oil palm (Elaeis guineensis), a perennial crop, is only felled every 25 years of its life cycle for replanting. Besides producing oil, the palm also produces other forms of biomass in abundance. During replanting, an estimated 209200 ha of oil palm trees were felled from 5.23 million ha of oil palm planted area in 2013 (MPOB, 2013). Currently, some of the felled oil palm trunks (OPT) are transported to the intended destination e.g. plywood factory, where the trunks are processed to remove the bark and sap so that the biomass produced can be used to manufacture furniture. Typically, the sap of OPT will not be utilised and will be discarded as waste. According to Kosugi and Mori (2007), freshly felled OPT may contain up to $70-85 \%$ of sap based on the weight of the whole trunk. The amount of fermentable sugars was found nearly $10 \%$ from the sap of the inner trunk. The squeezed sap contained an abundance of fermentable sugars and could be directly converted into bioethanol by microbial fermentation. Ethanol production via fermentation of sugars may provide an economically competitive source of energy by substituting gasoline.
Ethanol fermentation is a complex biochemical process with yeast or bacteria utilising fermentable sugar as substrate for their growth and converting them into ethanol, carbon dioxide and other metabolic products (Asyraf et al., 2011). Among the important factors affecting ethanol fermentation, culture conditions play a significant role in microbial growth as well as ethanol production. During ethanol fermentation, most of the yeast cells suffer from various stresses, including sugar concentration, nutrient deficiency, temperature and $\mathrm{pH}$ (Yah et al., 2010). Thus, this study was carried out to explore the potential of OPT sap for bioethanol production aiming at optimising the fermentation conditions i.e. $\mathrm{pH}$, temperature, inoculum size, nitrogen source, dilution effect and growth medium utilising the sap of OPT in order to obtain high bioethanol yield.

\section{MATERIALS AND METHODS}

\section{Materials}

The sap of OPT used in this study was supplied by Epaga Venture and was sampled at Segamat Johor in Malaysia.

\section{${ }^{*}$ Corresponding author}


The sap was extracted by mechanical pressing from different parts of OPT (i.e. inner, outer) as depicted in Figure 1. Samples were sterilized at $110^{\circ} \mathrm{C}$ for $15 \mathrm{~min}$ and kept in a $-4{ }^{\circ} \mathrm{C}$ freezer prior to fermentation to avoid microbial contamination.

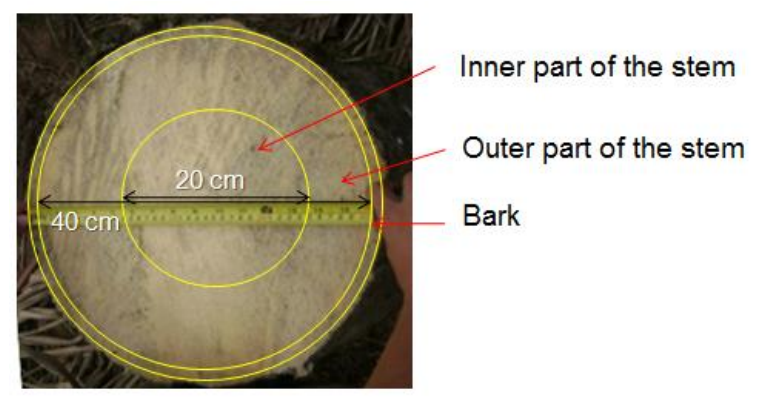

Figure1: Sample of sap of oil palm trunk.

\section{Optimisation of fermentation of OPT sap}

Fermentation of OPT sap was carried out using Saccharomyces cerevisea ATCC 24860 in shake flask. A single colony of freshly prepared $S$. cerevisiae was grown overnight in $10 \mathrm{~mL}$ yeast-peptone-glucose (YPD) [consisting of $1 \%(\mathrm{w} / \mathrm{v})$ yeast extract, $2 \%(\mathrm{w} / \mathrm{v})$ peptone, $2 \%(w / v)$ glucose] broth. This culture was used to inoculate $100 \mathrm{~mL}$ OPT sap in a $250-\mathrm{mL}$ Erlenmeyer flask, agitated at $150 \mathrm{rpm}$ for $96 \mathrm{~h}$. A total of six parameters were evaluated to optimise bioethanol production i.e. $\mathrm{pH}$, temperature, inoculum size, nitrogen source, substrate concentration and type of medium. In each of the experiment conducted, samples were harvested at predetermined time intervals, filtered and analysed for ethanol and sugar contents.

\section{Effect of initial $\mathrm{pH}$}

The effect of $\mathrm{pH}$ on fermentation of OPT sap was carried out by varying the $\mathrm{pH}$ from 3.5 to 6.0 at 0.5 interval. The OPT sap was adjusted to the desired $\mathrm{pH}$ using $1 \mathrm{M}$ hydrochloric acid $(\mathrm{HCl})$ or $1 \mathrm{M}$ sodium hydroxide $(\mathrm{NaOH})$ prior to inoculating with standardized $S$. cerevisiae. It was incubated at $30{ }^{\circ} \mathrm{C}$ with an agitation rate of $150 \mathrm{rpm}$ for 96 h.

\section{Effect of temperature}

The effect of temperature on fermentation of OPT sap was carried out by varying the temperature at $30^{\circ} \mathrm{C}, 35^{\circ} \mathrm{C}$ and $40^{\circ} \mathrm{C}$. The sap sample was incubated at the optimum $\mathrm{pH}$ obtained from the $\mathrm{pH}$ optimization study.

\section{Effect of inoculum size}

The effect of inoculum size on fermentation of OPT sap was carried out by varying the inoculum concentration from $5 \%$ to $20 \%(\mathrm{v} / \mathrm{v})$. The sap sample was incubated at the optimum $\mathrm{pH}$ and temperature obtained from above.

\section{Effect of nitrogen sources}

The effect of nitrogen source on fermentation of OPT sap was studied in five different nitrogen sources i.e. yeast extract, meat extract, peptone, urea and ammonium chloride $\left(\mathrm{NH}_{4} \mathrm{Cl}\right)$ at $1 \%(\mathrm{w} / \mathrm{v})$. The sap sample was incubated at the above optimum fermentation conditions.

\section{Effect of substrate concentration}

The substrate concentration was adjusted by diluting OPT sap with sterilized distilled water to the desired medium concentration ranging from $25 \%$ to $90 \%(\mathrm{v} / \mathrm{v})$. The undiluted sample was $100 \%(\mathrm{v} / \mathrm{v})$. The sap sample was incubated at the above optimum fermentation conditions.

\section{Effect of type of medium}

Three types of medium were selected to compare their performance on fermentation of OPT sap i.e. defined medium $\left(0.5 \% \mathrm{w} / \mathrm{v} \mathrm{KH}_{2} \mathrm{PO}_{4}, 0.2 \% \mathrm{w} / \mathrm{v}\left(\mathrm{NH}_{4}\right)_{2} \mathrm{SO}_{4}, 0.04 \%\right.$ $\mathrm{w} / \mathrm{v} \mathrm{MgSO}_{4} \cdot 7 \mathrm{H}_{2} \mathrm{O}, 0.15 \% \mathrm{w} / \mathrm{v}$ yeast extract, $5 \% \mathrm{w} / \mathrm{v}$ glucose); rich medium (YPD; $1 \% \mathrm{w} / \mathrm{v}$ yeast extract, $2 \%$ $\mathrm{w} / \mathrm{v}$ peptone, $5 \% \mathrm{w} / \mathrm{v}$ glucose), minimal medium $(6 \% \mathrm{w} / \mathrm{v}$ glucose, $1 \% \mathrm{w} / \mathrm{v}$ fructose). The sap sample was incubated in the respective medium at the above optimum fermentation conditions.

\section{Product analysis}

The moisture content of OPT sample was determined by drying in an oven at $105{ }^{\circ} \mathrm{C}$ for $24 \mathrm{~h}$. The fermentable sugar content of OPT sap and the bioethanol concentration were determined using high performance liquid chromatography (HPLC) (Waters 2707); Sugar Pack ${ }^{\mathrm{TM}}$ column: 6.5 × $300 \mathrm{~mm}$, detector temperature: 35 ${ }^{\circ} \mathrm{C}$, column temperature: $75^{\circ} \mathrm{C}$, flow rate: $0.5 \mathrm{~mL} / \mathrm{min}$ and injector volume of $1 \mu \mathrm{L}$. The ethanol yield $\left(\mathrm{Y}_{\mathrm{p} / \mathrm{s}}\right)$ was calculated based on experimental ethanol produced and expressed as $\mathrm{g}$ ethanol per total $\mathrm{g}$ of sugar utilised $(\mathrm{g} / \mathrm{g})$ (Eq. 1) and the ethanol formation rate was calculated based on ethanol yield obtained against maximum production time, $\Delta t$ (Eq. 2). The fermentation efficiency was calculated as ethanol produced against theoretical maximum ethanol yield from sugar (i.e. $0.51 \mathrm{~g}$ ethanol per g sugar) (Eq. 3).

$$
\begin{aligned}
& \text { Ethanol yield }\left(\mathrm{Y}_{\mathrm{p} / \mathrm{s}}\right)=\frac{(\text { Ethanol, } \mathrm{g} / \mathrm{L})}{(\text { Glucose, } \mathrm{g} / \mathrm{L})} \\
& \text { Ethanol formation rate }=\frac{(\text { Ethanol, } \mathrm{g} / \mathrm{L})}{\Delta \mathrm{t}} \\
& \text { Efficiency }(\%)=\frac{(\text { Ethanol, } \mathrm{g} / \mathrm{L})}{(\text { Glucose }, \mathrm{g} / \mathrm{L}) \times 0.51} \times 100 \\
& \text { (Eq. 2) } \\
& \text { Cell concentration in fermentation broth was } \\
& \text { determined by spectrophotometer (Genesys 20, Thermo } \\
& \begin{array}{l}
\text { Scientific, USA) at } 600 \mathrm{~nm} \text { absorbance. The medium was } \\
\text { diluted with distilled water } 1: 1 \text { accordingly. }
\end{array}
\end{aligned}
$$




\section{Statistical analysis}

All the experiments related to fermentation parameters were carried out in triplicate and the data was analysed using Minitab ${ }^{\circledR} 16$ by performing an analysis of variance (ANOVA) followed by Tukey's multiple comparison test. Level of statistical significance was set at $5 \%(p<0.05)$.

\section{RESULTS AND DISCUSSION}

\section{Sugar compositions}

The composition of fermentable sugars in the sap from inner and outer parts of OPT are shown in Table 1. The sap extracted from the inner part of OPT showed the highest concentration of fermentable sugar containing mainly glucose, i.e. $89.3 \mathrm{~g} / \mathrm{L}$. The higher sugar content in the inner part may be due to the presence of greater amount of soft parenchyma tissue compared to the outer part of OPT.

Table 1: Compositions of fermentable sugars in the sap from different parts of oil palm trunk.

\begin{tabular}{ccccc}
\hline $\begin{array}{c}\text { Part } \\
\text { of } \\
\text { OPT }\end{array}$ & $\begin{array}{c}\text { Moisture } \\
\text { content } \\
(\%)\end{array}$ & $\begin{array}{c}\text { Glucose } \\
(\mathrm{g} / \mathrm{L})\end{array}$ & $\begin{array}{c}\text { Fructose } \\
(\mathrm{g} / \mathrm{L})\end{array}$ & $\begin{array}{c}\text { Total } \\
\text { fermentable } \\
\text { sugars }(\mathrm{g} / \mathrm{L})\end{array}$ \\
\hline Inner & 67.10 & 89.30 & 4.61 & 93.91 \\
Outer & 66.58 & 16.06 & 0.91 & 16.97 \\
\hline
\end{tabular}

\section{Bioethanol production from OPT sap}

\section{Effect of initial $\mathrm{pH}$}

The effect of different $\mathrm{pH}$ on bioethanol production is shown in Figure 2. The highest bioethanol yield was obtained at $\mathrm{pH} 3.5$ with a maximum ethanol concentration of $46.47 \pm 1.62 \mathrm{~g} / \mathrm{L}$ followed closely by $\mathrm{pH} 4.0$ with $46.30 \pm$ 2.79 at $24 \mathrm{~h}$ of fermentation. However, the effect between these $\mathrm{pH}$ values was not statistically significant (Table 2). Fermentation at $\mathrm{pH} 4.0$ performed better in longer fermentation period compared to other $\mathrm{pH}$ values tested. Therefore, this $\mathrm{pH}$ was used in all the following experiments for optimisation. Since the $\mathrm{pH}$ of OPT sap was well within the range, it was used without requiring further $\mathrm{pH}$ modification.

It has been reported that $\mathrm{pH}$ could influence significantly on fermentation, mainly on yeast growth, fermentation rate and by-product formation (Sheela et al., 2008). During yeast growth, an acidic intracellular $\mathrm{pH}$ must be preserved and maintained for optimal microbial performance, due to the acidophilic nature of the yeast itself. When the extracellular $\mathrm{pH}$ deviates from the optimal level, the yeast cells need to invest more energy to either pump in or pump out $\mathrm{H}^{+}$in order to maintain the optimal intracellular $\mathrm{pH}$, failing which the yeast may not function normally. In this case, the yeast cell will not be able to grow and produce ethanol efficiently (Narendranath et al., 2001).
The $\mathrm{pH}$ affects the functioning of microbial cells enzyme and the transport of nutrients into the cell (Chooklin et al., 2011). The results obtained from this study showed that the most suitable $\mathrm{pH}$ for bioethanol production from OPT sap was at $\mathrm{pH}$ 3.5-4.0. Increasing $\mathrm{pH}$ value could reduce bioethanol production as well as glucose consumption rate. Higher $\mathrm{pH}$ increases the permeability of the cell membrane resulted in the reduction of sugar conversion rate and ethanol yield. Besides, formation of undesired product such as glycerol and organic acid in less acidic $\mathrm{pH}$ may also take place during the fermentation process (Pramanik, 2003). The results obtained was in agreement with Manikandan et al., (2008) who also reported that yeast growth and fermentation process performed the best in slightly acidic environment.

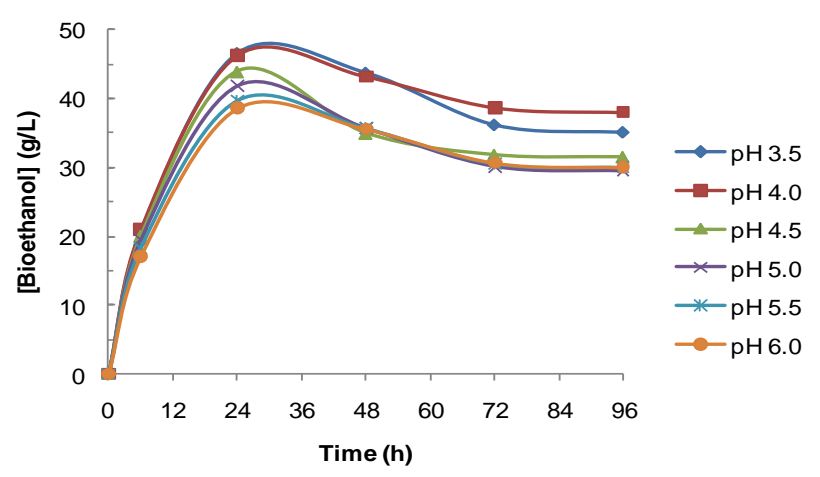

Figure 2: Bioethanol production from oil palm trunk sap at different $\mathrm{pH}$.

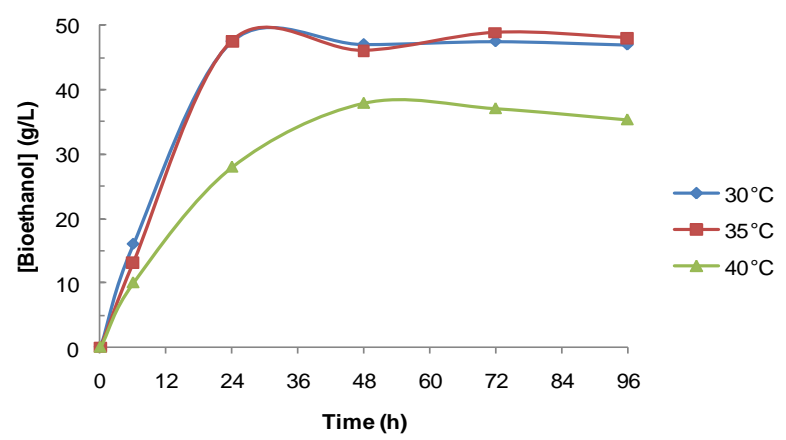

Figure 3: Bioethanol production from oil palm trunk sap at different reaction temperatures.

\section{Effect of temperature}

The effect of different temperature on bioethanol production is shown in Figure 3 . The highest yield of bioethanol was obtained at $30-35{ }^{\circ} \mathrm{C}$ after $24 \mathrm{~h}$ of fermentation with $47.53 \pm 0.19$ and $47.54 \pm 0.09 \mathrm{~g} / \mathrm{L}$, respectively. However, the effect between these temperatures was not statistically significant (Table 2). Fermentation at $40{ }^{\circ} \mathrm{C}$, on the other hand, showed a significant fall in ethanol yield and productivity $(p<0.05)$. Clearly, higher temperature was found unsuitable and less 
efficient than lower temperature for bioethanol production by $S$. cerevisiea, as was indicated after $24 \mathrm{~h}$ of fermentation at $40{ }^{\circ} \mathrm{C}$ producing only $27.93 \pm 0.52 \mathrm{~g} / \mathrm{L}$ ethanol corresponded to $58 \%$ fermentation efficiency. This finding is in agreement with that studied by Yah and coworkers (2010), showing similar trend in bioethanol production at temperature $>40{ }^{\circ} \mathrm{C}$ using different feedstock such as sugarcane molasses, baggases, corncorb and sweet sorghum hydrolysate by $S$. cerevisiea. A decline in bioethanol yield at $\geq 40{ }^{\circ} \mathrm{C}$ might be due to the inactivation of enzyme in ethanol production pathways, leading to loss of enzyme activity and lipid metabolisms, disruption of enzyme, alteration of membrane structure and decreased functionality, hence resulted in low bioethanol production (Pramanik, 2003; Sharma et al., 2007; Sener et al., 2007; Beltran et al., 2008). In this study, an incubation temperature of $30{ }^{\circ} \mathrm{C}$ was chosen to optimise bioethanol production from OPT sap.

Table 2: Effect of different fermentation parameters (i.e. $\mathrm{pH}$, temperature, inoculum size and nitrogen source on bioethanol production from oil palm trunk (OPT) sap at $24 \mathrm{~h}$ of fermentation.

\begin{tabular}{|c|c|c|c|c|c|}
\hline \multicolumn{2}{|c|}{ Fermentation parameters } & $\begin{array}{l}\text { Ethanol concentration } \\
(\mathrm{g} / \mathrm{L})\end{array}$ & $\begin{array}{l}\text { Productivity } \\
\text { (g/L/h) }\end{array}$ & $\begin{array}{l}\text { Ethanol yield, } \\
Y_{p / s}(g / g)\end{array}$ & $\begin{array}{l}\text { Fermentation } \\
\text { efficiency (\%) }\end{array}$ \\
\hline \multirow[t]{6}{*}{$\mathrm{pH}$} & 3.5 & $46.47 \pm 1.62^{a}$ & 1.936 & 0.495 & 96.8 \\
\hline & 4.0 & $46.30 \pm 2.79^{a}$ & 1.929 & 0.493 & 96.5 \\
\hline & 4.5 & $43.91 \pm 3.48^{\mathrm{ab}}$ & 1.830 & 0.468 & 91.5 \\
\hline & 5.0 & $41.80 \pm 3.56^{b}$ & 1.742 & 0.445 & 87.1 \\
\hline & 5.5 & $39.71 \pm 2.48^{b}$ & 1.655 & 0.423 & 82.8 \\
\hline & 6.0 & $38.59 \pm 2.00^{b}$ & 1.608 & 0.411 & 80.4 \\
\hline \multirow[t]{3}{*}{ Temperature $\left({ }^{\circ} \mathrm{C}\right)$} & 30 & $47.53 \pm 0.19^{a}$ & 1.980 & 0.50 & 99.0 \\
\hline & 35 & $47.54 \pm 0.09^{a}$ & 1.981 & 0.50 & 99.0 \\
\hline & 40 & $27.93 \pm 0.52^{b}$ & 1.164 & 0.30 & 58.1 \\
\hline & 5 & $37.52 \pm 4.36^{\mathrm{a}}$ & 1.563 & 0.40 & 78.2 \\
\hline \multirow{3}{*}{$(\%, v / v)$} & 10 & $45.84 \pm 1.11^{a}$ & 1.910 & 0.49 & 95.5 \\
\hline & 15 & $41.06 \pm 2.28^{a}$ & 1.711 & 0.44 & 85.6 \\
\hline & 20 & $42.90 \pm 1.07^{\mathrm{a}}$ & 1.788 & 0.46 & 89.4 \\
\hline \multirow[t]{6}{*}{ Nitrogen source } & YE & $45.12 \pm 0.36^{a}$ & 1.880 & 0.50 & 97.0 \\
\hline & ME & $43.16 \pm 1.07^{\mathrm{a}}$ & 1.798 & 0.47 & 92.8 \\
\hline & Peptone & $42.90 \pm 0.96^{a}$ & 1.788 & 0.47 & 92.2 \\
\hline & Urea & $38.08 \pm 1.64^{b}$ & 1.587 & 0.42 & 81.9 \\
\hline & $\mathrm{NH}_{4} \mathrm{Cl}$ & $42.38 \pm 0.75^{a}$ & 1.766 & 0.47 & 91.1 \\
\hline & Control & $43.60 \pm 0.78^{a}$ & 1.817 & 0.48 & 93.8 \\
\hline
\end{tabular}

Values are mean concentration \pm standard deviation of triplicate determination. Means bearing different letter in a column are significantly different $(p<0.05)$.

\section{Effect of inoculums size}

As excessive inoculum in the medium compromises fermentation rate, ethanol production and recovery (Jones et al., 2007), a suitable and optimal inoculums size is critical to achieve more efficient bioethanol production from OPT sap. Figure 4 shows bioethanol production profile from OPT sap at different initial inoculum size. The highest bioethanol concentration of $45.84 \pm 1.11 \mathrm{~g} / \mathrm{L}$ was obtained from OPT sap inoculated with $10 \%(\mathrm{v} / \mathrm{v}) S$. cerevisiae for $24 \mathrm{~h}$. Increasing the inoculum size beyond $10 \%(\mathrm{v} / \mathrm{v})$ resulted in a declined bioethanol yield However, the effect of different inoculum size on bioethanol production in this study was statistically insignificant $(p>0.05)$ as shown in Table 2. From this finding, the inoculum size of $10 \%(\mathrm{v} / \mathrm{v})$ that showed the highest bioethanol formation rate of $1.91 \mathrm{~g} / \mathrm{L} / \mathrm{h}$ and $96 \%$ fermentation efficiency was used to optimise bioethanol production from OPT sap.

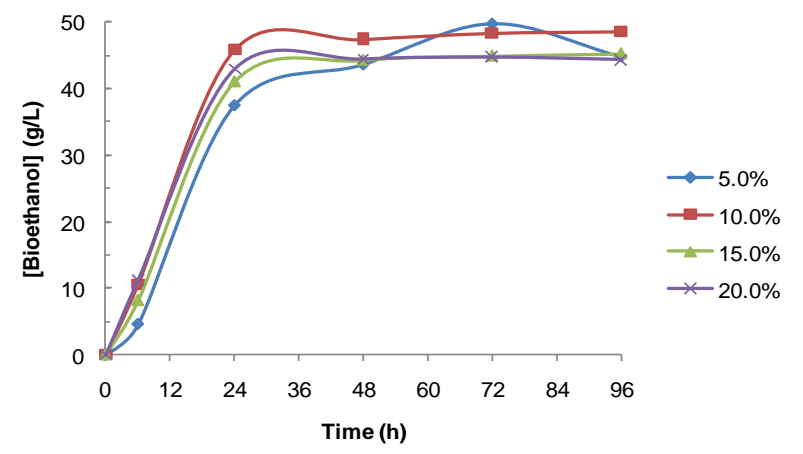

Figure 4: Bioethanol production from oil palm trunk sap at different inoculum sizes.

\section{Effect of nitrogen source}

An investigation on fermentation of OPT sap with various nitrogen supplements and non-supplemented control 
revealed that nitrogen sources i.e. yeast extract (YE), meat extract (ME), peptone and $\mathrm{NH}_{4} \mathrm{Cl}$ did not significantly influence bioethanol production (Figure 5). However, YE could provide a better positive attribute for the process than the control and other supplementation as it has tendency to shorten the fermentation period due to a higher productivity i.e. $1.88 \mathrm{~g} / \mathrm{L} \cdot \mathrm{h}$ (Table 2). On the other hand, addition of urea had significantly reduced bioethanol production $(p<0.05)$ as was evident by a lower growth curve, productivity and fermentation efficiency (Figure 4, Table 2). Conclusively, urea is not a suitable additive for bioethanol production from OPT sap.

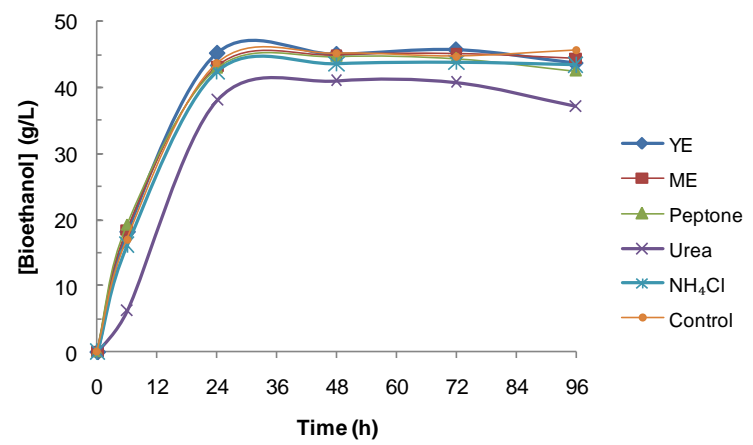

Figure 5: Bioethanol production from oil palm trunk sap at different nitrogen sources.

An additional nitrogen source is necessary to accelerate the growth and multiplication of yeast, and it influences the ethanol tolerance of yeast and the ultimate ethanol productivity (Bafrncova et al., 1999). However, in this study, the addition of various nitrogen sources to OPT sap did not show any significant influence on bioethanol production. Bafrncova and co-workers (1999) also demonstrated that an additional nitrogen source was not able to increase bioethanol productivity, although it increased glucose consumption rate by up to three times than that of the control. Since the added YE showed negligible increase in bioethanol production from OPT sap, its addition was not necessary.

\section{Effect of substrate concentration}

The ability of $S$. cerevisiae to utilise OPT sap as the sole carbon source was studied by using different concentrations of OPT sap during fermentation (Figure 6). The undiluted raw sap gave the highest yield of bioethanol since the initial sugars concentration was the highest among the others. This showed that $S$. cerevisiae was able to utilise $100 \%$ (v/v) OPT sap without much problem encountered in the reaction concerning product inhibitory and or insufficient dispersion of substrate in too concentrated medium (Lu et al., 2008; Hodge et al., 2008). The effect of different substrate concentration in fermentation efficiency of OPT sap was found insignificant $(p>0.05)$ as high ethanol yield could be achieved in all substrate concentrations (Table 3).

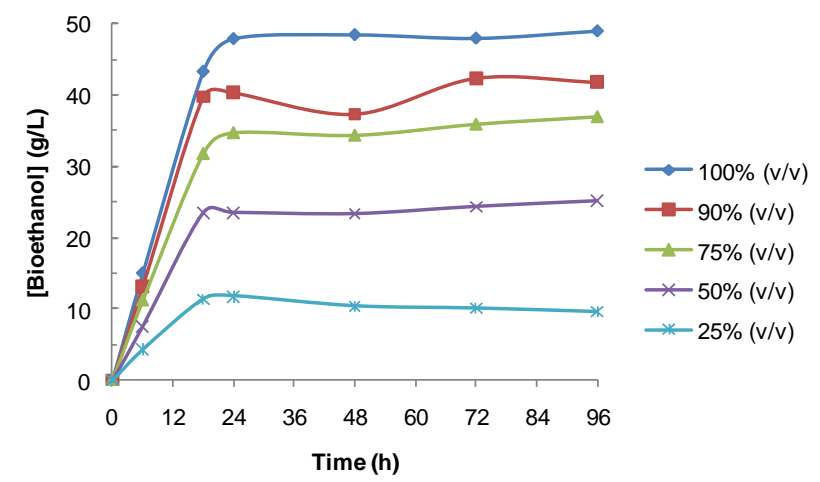

Figure 6: Bioethanol production from oil palm trunk sap at different substrate concentration.

Table 3: Effect of dilution and fermentation medium on bioethanol production from oil palm trunk (OPT) sap at $24 \mathrm{~h}$ of fermentation.

\begin{tabular}{|c|c|c|c|c|c|}
\hline & $\begin{array}{c}\text { Initial sugar } \\
\text { concentration(g/L) }\end{array}$ & $\begin{array}{c}\text { Ethanol } \\
\text { concentration(g/L) }\end{array}$ & $\begin{array}{l}\text { Productivity } \\
\text { (g/L/h) }\end{array}$ & $\begin{array}{c}\text { Ethanol yield, } \\
Y_{p / s}(g / g)\end{array}$ & $\begin{array}{l}\text { Fermentation } \\
\text { efficiency (\%) }\end{array}$ \\
\hline \multicolumn{6}{|l|}{ Dilution (\%, v/v) } \\
\hline 100 (undiluted) & 93.91 & $47.55 \pm 0.48$ & 1.981 & 0.50 & $99.1^{a}$ \\
\hline 90 & 86.82 & $39.99 \pm 2.53$ & 1.667 & 0.46 & $90.1^{a}$ \\
\hline 75 & 74.05 & $34.93 \pm 0.81$ & 1.455 & 0.47 & $92.3^{a}$ \\
\hline 50 & 49.64 & $23.70 \pm 0.54$ & 0.975 & 0.48 & $93.4^{a}$ \\
\hline 25 & 22.56 & $10.72 \pm 0.91$ & 0.447 & 0.48 & $93.0^{a}$ \\
\hline \multicolumn{6}{|l|}{ Type of medium } \\
\hline Defined (basal salts) & 60.0 & $29.41 \pm 0.94$ & 1.225 & 0.49 & $96.1^{\mathrm{a}}$ \\
\hline Rich (YPD) & 60.0 & $28.97 \pm 0.49$ & 1.207 & 0.48 & $94.7^{\mathrm{a}}$ \\
\hline Minimal (only C-source) & 70.0 & $27.65 \pm 2.54$ & 1.152 & 0.40 & $77.5^{b}$ \\
\hline OPT sap (control) & 93.9 & $47.54 \pm 0.27$ & 1.981 & 0.50 & $99.3^{a}$ \\
\hline
\end{tabular}

Values are fermentation efficiency of triplicate determination. Means bearing different letter in a column are significantly different $(p<$ 0.05 ). 
Distillation of fermentation broth to obtain purer ethanol is energy demanding especially in the case if the broth has lower ethanol concentration (Olsson and HahnHagerdal, 1996). It is thus preferable to work on substrate having high concentrations, i.e. high fermentable sugars concentrations and its resulting high ethanol concentrations in industrial processes. In this study, it was evident that a sugar concentration up to $94 \mathrm{~g} / \mathrm{L}$ did not give any negative effect to the yeast cell. Thus, the undiluted OPT sap can be directly used in ethanol fermentation as $S$. cerevisiae has high ethanol tolerance up to $10 \%(\mathrm{v} / \mathrm{v})$.

\section{Type of medium}

The performance of $S$. cerevisiae in reference media i.e. rich medium (YPD), defined medium (basal salts) and minimal medium (only carbon sources) vs. OPT sap for bioethanol productivity were shown in Figure 7 . It demonstrated that OPT sap had sufficient nutrients to support fermentation by $S$. cerevisiae, and may not contain inhibiting substances. S. cerevisiae performed the best in OPT sap although the efficiency (99\%) was not significantly different as compared to those in the reference media i.e. YPD and defined medium. However, minimal medium showed the worst with only $78 \%$ fermentation efficiency $(p<0.05)$ (Table 3$)$. This was attributed in part to an absence of essential nutrients and nitrogen source for yeast growth thus lowering the yield of bioethanol. OPT sap, on the other hand, contains lots of amino acids (serine, alanine, glutamic acid and aspartic acid), organic acids (citric, malic and maleic acids), vitamins (vitamin B and C) and minerals (calcium, magnesium and chloride) (Kosugi et al., 2010), hence it is a good medium for yeast growth in fermentation.

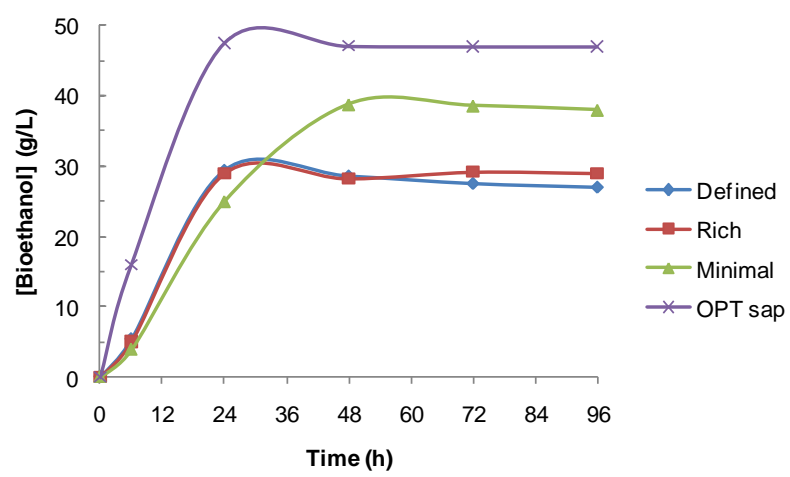

Figure 7: Bioethanol production from oil palm trunk sap and other reference media - rich, defined and minimal.

Table 4: Comparison of bioethanol production from various renewable substrates.

\begin{tabular}{lllll}
\hline Strain & Substrate & $\begin{array}{l}\text { Sugar conc. } \\
(\mathrm{g} / \mathrm{L})\end{array}$ & $\begin{array}{l}\text { Ethanol yield, } \\
\mathrm{Y}_{\mathrm{p} / \mathrm{s}}(\mathrm{g} / \mathrm{g})\end{array}$ & Reference \\
\hline S. cerevisiae (strain DTN) & Sugar beet thick juice & 100 & 0.43 & $\begin{array}{l}\text { Razmovski and } \\
\text { Vucurovic, 2012 } \\
\text { S. cerevisiae (drying baking }\end{array}$ \\
$\begin{array}{l}\text { yeast) } \\
\begin{array}{l}\text { S. cerevisiae (commercial } \\
\text { Bakers yeast, Mauripan) }\end{array}\end{array}$ & $\begin{array}{l}\text { juice } \\
\text { S. cerevisiae Kyokai no. } 7\end{array}$ & OPF juice & 0.39 & Zahari et al., 2013 \\
$\begin{array}{l}\text { S. cerevisiae ATCC 24860 } \\
\text { OPT sap }\end{array}$ & OPT sap & 53 & 0.49 & Kosugi et al., 2010 \\
\hline
\end{tabular}

The OPT sap yielded $0.50 \mathrm{~g}$ ethanol $/ \mathrm{g}$ sugars employing the optimised fermentation conditions. This value is slightly higher compared to that of ethanol produced from OPT sap in another study (Kosugi et al., 2010) and other renewable liquid resources as reported previously using various different strains of $S$. cerevisiae (Table 4). The result suggests that OPT sap has a great potential as fermentation substrate for ethanol production. The procedure is rather straightforward; which does not require any additional nitrogen and nutrient supplementation, $\mathrm{pH}$ adjustment and can be operated at ambient temperature.

\section{CONCLUSION}

The study has clearly demonstrated that high efficient bioethanol production from OPT sap is possible but it is influenced by various fermentation parameters. A total of $63 \mathrm{~g} / \mathrm{kg}$ of fermentable sugars from inner part of OPT can be converted into $40 \mathrm{~L}$ /tonne bioethanol employing the optimised fermentation conditions described in this study. This process has potential to be scaled up to either pilot or commercial production, making the process more economical. This study has also established that OPT sap from the plywood industries which has not been exploited commercially for any industrial application and is poorly disposed of could be utilised effectively for biofuel production.

\section{ACKNOWLEDGEMENTS}

This work was supported by Malaysian Palm Oil Board (MPOB). The technical assistance provided by the staff of the Energy and Environment Unit of MPOB is deeply appreciated. 


\section{REFERENCES}

Asyraf, M. K., Loh S. K., Nasrin, A. B., Astimar, A. A. and Rosnah M. S. (2011). Bioethanol production from enzymatically saccharified empty fruit bunches hydrolysate using Saccharomyces cerevisiae. Research Journal of Environmental Sciences 5(6), 573-586.

Bafrncova, P., Smogrovicova, D., Slavikova, I., Patkova, J. and Domeny, Z. (1999). Improvement of very high gravity ethanol fermentation by media supplementation using Saccharomyces cerevisiae. Biotechnology Letters 21, 337-341.

Beltran, G., Novo, M., Guillamon, J. M. Mas, A. and Rozes, N. (2008). Effect of fermentation temperature and culture media on the yeast lipid composition and wine volatile compounds. International Journal of Food Microbiology 121, 169-177.

Chooklin, S., Kaewsichan, L. and Kaewsrichan, J. (2011). Potential utilization of sap from oil palm (Elaeis guineensis) for lactic acid production by Lactobacillus casei. Journal of Sustainable Energy and Environment 2, 99-104.

Hodge, D., Karim, K. M., Schell, D. J. and McMillan, D. (2008). Soluble and insoluble solid contribution to high solid enzymatic hydrolysis of lignocellulosic. Bioresource Technology 99 (18), 8940-8948.

Jones, H. L., Margaritis, A. and Stewart, R. J. (2007). The combined effects of oxygen supply strategy, inoculums size and temperature profile on very-highgravity beer fermentation by Saccharomyces cerevisiae. Journal of the Institute of Brewing 113 (2), 168-184.

Kosugi, A. and Mori, Y. (2007). Ethanol and lactic acid production from oil palm trunk. http://ss.jircas.affrc.go.jp.

Kosugi, A., Tanaka, R., Magara, K., Murata, Y., Arai, T., Othman, S., Rokiah, H., Zubaidah Aimi, A. H., Mohd Khairul Azri, Y., Mohd Nor, M. Y., Wan Asma, I. and Mori, Y. (2010). Ethanol and lactic acid production using sap squeezed from old oil palm trunks felled for replanting. Journal of Bioscience and Bioengineering 110 (3), 322-325.

Lu, Y., Wang, Y. Xu, G. Chu, J. Zhuang, Y. and Zhang, S. (2008). Influence of high solid concentration on enzymatic hydrolysis and fermentation of steamexploded corn stover biomass. Applied Biochemical and Biotechnology 160, 360-369.

Mairan, G., Claudia, L., Leticia, V. P., Maria, E. L., Daniel, V. and Mario, D. F. (2011). Bioethanol production from sweet sorghum: Evaluation of postharvest treatments on sugar extraction and fermentation. Biomass and Bioenergy 35, 3058-3062.

Malaysian Palm Oil Board (MPOB) (2013). Malaysian oil palm statistics 2013 33rd Edition. Ministry of Plantation Industries and Commodities. Kuala Lumpur.
Manikandan, K., Saravanan, V. and Viruthagiri, T. (2008). Kinetics studies on ethanol production from banana peel waste using mutant strain of Saccharomyces cerevisiae. Indian Journal of Biotechnology 7, 83-88.

Narendranath, N. V., Thomas, K. C. and Ingledew, W. M. (2001). Acetic acid and lactic acid inhibition of growth of Saccharomyces cerevisiae by different mechanisms. Journal of the American Society of Brewing Chemists 59, 187-194.

Olsson, L. and Hahn-Hagerdal, B. (1996). Fermentation of lignocellulosic hydrolysates for ethanol production. Enzyme and Microbial Technology 18, 312-331.

Pramanik, K. (2003). Parametric studies on batch alcohol fermentation using Saccharomyces yeast extracted from toddy. Journal of the Chinese Institute of Chemical Engineers 4, 487-492.

Razmovski, R. and Vucurovic, V. (2012). Bioethaanol production from sugar beet molasses and thick juice using Saccharomyces cerevisiae immobilized on maize stem ground tissue. Fuel 92(1), 1-8.

Sener, A., Cnabas, A. and Unal, M. U. (2007). The effect of fermentation temperature on the growth kinetics of wine yeast species. Turkey Journal of Agriculture 31, 349-354.

Sharma, N., Kalra, K. L., Oberoi, H. S. and Bansal, S. (2007). Optimization of fermentation parameters for production of ethanol from kinnow waste and banana peels by simultaneous saccharification and fermentation. Indian Journal of Microbiology 47, 310316.

Sheela, S. H., Ahmed, M. F. and Gomez, D. J. (2008). Fuel ethanol production from molasses by some indigenous yeast isolates. Bangladesh Journal Microbiology 25, 129-133.

Yah, C. S., lyuke, S. E., Unuabonah, E. I., Vishanta, O. P. C. and Tessa, S. M. (2010). Temperature optimization for bioethanol from corn cobs using mixed yeast strain. Online Journal of Biological Sciences 10, 103-108.

Zahari, M. A. K. M., Syed Abdullah, S. S., Roslan, A. M., Ariffin, H., Shirai, Y. and Hassan, M. A. (2013). Efficient utilization of oil palm frond for bio-based products and biorefinery. Journal of Cleaner Production 65, 252-260. 